\title{
Identification and Mapping of Prone to Landslide in the Sub District of Kintamani, Bali Province, Indonesia
}

\author{
Made Sri Sumarniasih
}

Faculty of Agriculture, Udayana University, Indonesia

\begin{abstract}
This research was conducted in several locations of prone to landslides in the Sub District of Kintamani, Bangli Regency, Bali Province, Indonesia. Determining the research location is purposively, meaning intentionally determined by observing in the field to landslides during the rainy season 2016/2017. The purpose of research, namely: (1) identifying areas prone to landslides at several locations in the Sub District of Kintamani, Bangli Regency; (2) to mapping areas prone to landslides using geographical information systems (GIS), (3) to formulate the strategies to overcome landslides. The analytical method used is descriptive-qualitative, meaning that the results of field observations and interviews integrated and interpreted in a narrative-qualitative. Results of the analysis showed that the location is prone to landslides in the sub district of Kintamani are Villages of Selulung, Satra, Tanah Gambir, Tegallinggah, Pinggan, Songan, Kayu Selem, Blancan, Batur, Bubung Kelambu, Pura Tanah Mas, Mampeh, Yeh Mampeh, dan Penelokan, with total area of 144,36 ha. The cause of landslides are high rainfall, soil type regosol, geology, slope average above $15 \%$ and the use of land that is not paying more attention on land conservation. Further mapping of landslide-prone locations using Q-GIS and Google Earth. Strategies to overcome landslides is to avoid the cultivation of agriculture in areas prone to landslides, implement agroforestry systems, planting cover crops, making sewers or ditches, enforcing the rules of the spatial region and violators are given strict and severe sanctions.
\end{abstract}

Keywords-Mapping, Landslides, Kintamani.

\section{INTRODUCTION}

Indonesia, including Bali as a one of Province in Indonesia is an area prone to natural disasters, caused by over-exploitation of natural resources, land conversion, improper land use, and global climate change such as the prolonged rainy season in 2016/2017. Natural disasters can occur suddenly or slowly, earthquakes, tsunamis and volcanoes are almost impossible to estimate accurately, when will happen and how much strength. While floods, landslides, droughts are predictable. In the rainy season there are two disaster threats namely floods and landslides. Floods and landslides occasionally occur respectively. Continuous floods will erode the land slopes of hills or mountains, so if the construction of the soil is unstable it will happened landslide.

Bali's concerns were struck by the disaster as Lanina's impact during the rainy season of December 2016 to February 2017, becoming a reality; this is all due to Bali's nature already damaged from upstream to downstream. For example in sub district of Kintamani this year experienced the worst natural disaster during 20 years. The team from the Geological Agency has checked into the field, the Banjar of Bantas area in the middle of the hill of Kintamani is now in a vulnerable condition, due to the landslide that is easily landslide (Bali Post, 2017).

Suripin (2002) and Anwar, et al. (2003) stated that landslides are a form of erosion where the transport or movement of the soil mass occurs at one day in a relatively large volume. Mass that moves in the landslide is a large mass, so often the occurrence of landslides will bring the victim in the form of environmental damage, degradation of agricultural land, settlements damage and damage of infra structure and property and even the loss of human life. Landslides constitute the movement of slope-forming materials in the form of rocks, rickwheels, soils, or mixtures of such material moving down or out of the slopes. The process of occurrence of landslides starting from water that seep into the soil will increase the weight of the soil. If the water penetrates to the impermeable soil that acts as a slip plane, it will become slippery and the weathering soils on it will move along the slope and out of the slope. In principle, landslides occur if the driving force on the slope is greater than the retaining force. Retaining force is generally influenced by rock strength and soil density, whereas the driving force is usually influenced by the amount of inclination angle of the slope, water, load and soil type of rock. The causing factors the movement of the slope also depend on the conditions of rock and slope soil, geological structure, rainfall, cover of vegetation and land use on the slop. 
The potential for landslide disaster in Bali Province is 85,121,55 ha, and one of the regency prone to landslide is Bangli Regency. Some of the villages in sub district of Kintamani, Bangli regency are landslide-prone areas, because they are on steep slopes, especially in the upper reaches where the soil is dominated by sandy texture, has a high rainfall of about 2000 mm per day, so when it rains with high intensity and long, prone to landslide disaster (Bappeda Bali and PPLH Unud, 2006). The cause of landslide and its prevention is very important to know, so that it can minimize the occurrence of landslide and the resulting consequences (Law Number 24 Year 2007 on Disaster Management). So the disaster management plan is a manifestation of government efforts related to the formulation of activity programs and the focus of the priority of disaster management, then the characteristics of the disaster must be studied carefully.

Based on the previous description, the objectives of the research are: (1) to identify the affected areas and prone to landslide disaster in the sub district of Kintamani, Bangli regency, Bali Province, (2) to mapping the landslide prone area by using geographic information system (GIS); (3) formulate the strategies used to overcome the risk of landslide disaster.

\section{METHOD OF RESEARCH}

The research location in sub district of Kintamani, Bangli regency, Bali Province determined purposively, based on consideration: (1) Sub district of Kintamani is hilly area prone to landslide; (2) In March 2017, several locations in sub district of Kintamani were struck by landslides caused by heavy rains and prolonged rainy season of 2016/2017; (3) Until now no research has been done to mapping the landslide prone locations in sub district of Kintamani. The astronomy of sub district of Kintamani is at $8^{0} 7^{\prime} 42^{\prime \prime}, 8^{0} 18^{\prime} 53^{\prime \prime}$ LS dan $-115^{0} 10^{\prime} 44^{\prime \prime}$

The research method used survey method, ie observed the location of landslide disaster (Figure 1a, 1b, 1c), and interview with community in disaster location. The results of surveys and interviews were integrated and then mapped the landslide-prone locations using Q-GIS and Google Earth.

The analytical method used is descriptive qualitative, ie giving meaning to result of field observation and result of interview with community around research location, so that able to describe phenomenon that happened at research location that is sub district of Kintamani, Bangli Regency, Bali Province, Indonesia.

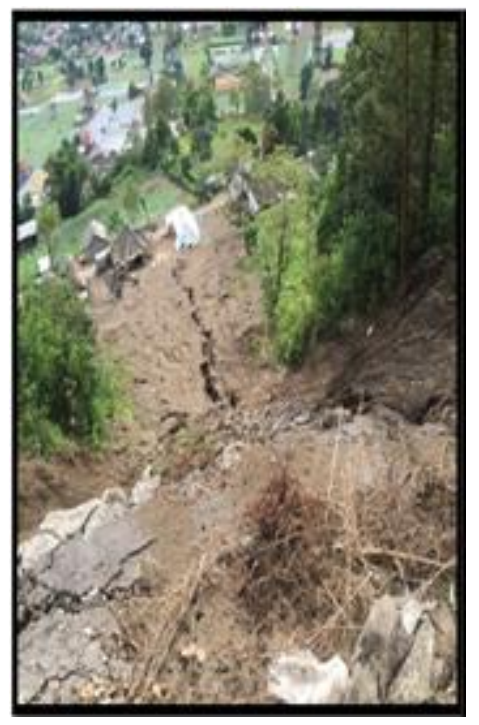

FigURE 1A. LANDSLIDE LOCATION IN SONGAN VILLAGE, SUB DisTRICT OF KINTAMANI

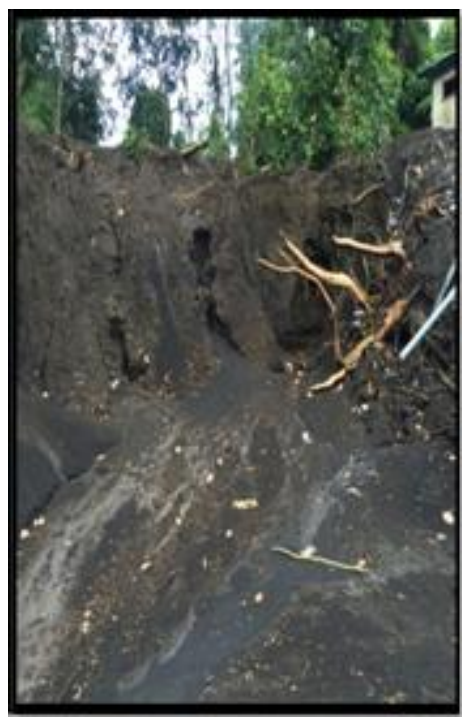

FIGURE 1B. LANDSLIDE LOCATIONS IN PENELOKAN VillaGe, SUB DiSTRICT OF KINTAMANI

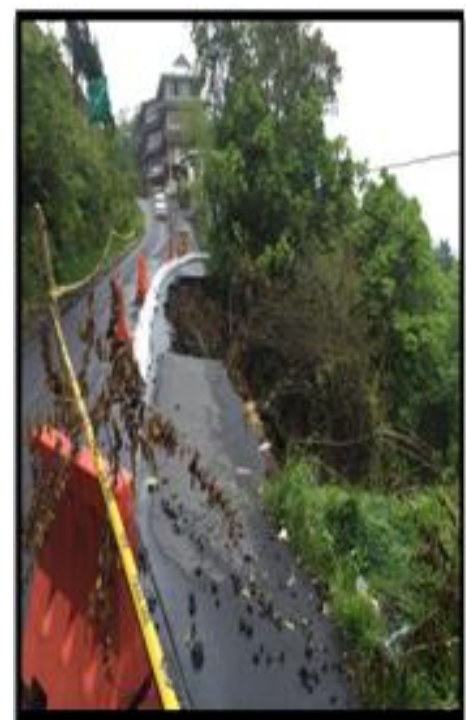

FIGURE 1C. LANDSLIDE LOCATION IN YEH MAMPAH VILlAGE SUB District OF KINTAMANI

\section{RESULTS AND DISCUSSION}

\subsection{Identify Landslide Prone Areas}

Based on observation and field identification, landslide disaster in sub district of Kintamani occurred in villages of Selulung, Satra, Tanah Gambir, Tegallinggah, Pinggan, Songan, Kayu Selem, Blancan, Batur Bubung Kelambu, Pura Tanah Mas, Mampeh, Yeh Mampeh, dan Penelokan with the extent of 144,36 ha is presented in Table 1. As a result of landslides in 
several villages in Kintamani, about 350 ha of agricultural land in the area was severely damaged. Estimated losses reach billions of rupiah. This was disclosed Head of Agriculture, Food Security and Fisheries of Bangli Regency Wayan Sukartana (Bali Post, 2017). The factors that cause landslide disaster are: rainfall, geological structure, soil type, slope inclination, land use that does not pay attention to the rules of land conservation.

Rainfall is the amount of rainwater that falls to the earth per unit surface area at a certain time period. The amount of rainfall can be expressed as the volume of rainwater that falls on a certain area for a relatively long period of time, and the amount of rainfall is expressed in $\mathrm{m}^{3}$ per unit area (Subekti et al., 2009). Karnawati (2003) stated that one of the factors causing the occurrence of landslide disaster is rain water. The compact and watertight rocks act as a water barrier and simultaneously as an avalanche slip, while water acts as a driving ground mass slipping over compact rocks. The steeper the slope, the faster the speed of slipping. The more loose the clay pile, the easier it will be to pass the water and the sooner the water seeps into the soil. The thicker the pile of soil, the greater the volume of landslide mass. While Setyolelono (2005) states that the influence of rain can occur in parts of the slopes that are open due to human activities, especially related to land use, less attention to patterns that have been applied by the government. For example, continuous logging of protected forests should not be done, so lands with very sloping geomorphology become open and prone to landslides.

TABLe 1.

LANDSLIDE LOCATION IN SUB DISTRICT OF KINTAMANI, BANGLI REGENCY, BALI PROVINCE, INDONESIA

\begin{tabular}{|c|c|c|c|c|c|c|}
\hline No. & Location & Villages & $\begin{array}{l}\text { Slope/ } \\
\text { Class }\end{array}$ & Soil Type & Land Use & $\begin{array}{c}\text { Cause } \\
\text { Landslide }\end{array}$ \\
\hline 1 & Selulung & Selulung & IV & Humus Regosol & $\begin{array}{c}\text { Dry land, garden mix, } \\
\text { Schrubs }\end{array}$ & Heavy rain \\
\hline 2 & Satra & Satra & III & Humus Regosol & $\begin{array}{c}\text { Dry land, garden mix, } \\
\text { Settlement }\end{array}$ & Heavy rain \\
\hline 3 & Tanah Gambir & Satra & III & Humus Regosol & $\begin{array}{c}\text { Dry land, garden mix, } \\
\text { Settlement }\end{array}$ & Heavy rain \\
\hline 4 & Tegallinggah & Sukewana & V & Gray Regosol & Shrubs, garden mix & Heavy rain \\
\hline 5 & Pinggan & Pinggan & III & Gray Regosol & Garden mix, schurbs & Heavy rain \\
\hline 6 & Songan & Songan B & V & Gray Regosol & Settlement, dry land & Heavy rain \\
\hline 7 & $\begin{array}{c}\text { Perbatasan Kayu } \\
\text { Selem }\end{array}$ & Blandingan & V & Gray Regosol & Dry land, garden mix & Heavy rain \\
\hline 8 & Blancan & Blancan & III & Humus Regosol & Garden mix, land berro & Heavy rain \\
\hline 9 & $\begin{array}{l}\text { Batur Bubung } \\
\text { Kelambu }\end{array}$ & Kintamani & IV & Gray Regosol & Dry land, garden mix & Heavy rain \\
\hline 10 & $\begin{array}{l}\text { Pura Tirta Mas } \\
\text { Mempeh }\end{array}$ & Sukawana & V & Gray Regosol & $\begin{array}{c}\text { Dry land, land berro, } \\
\text { schrubs }\end{array}$ & Heavy rain \\
\hline 11 & Yeh Mempeh & Sukawana & II & Gray Regosol & $\begin{array}{c}\text { Dry land, land berro, } \\
\text { schurbs }\end{array}$ & Heavy rain \\
\hline 12 & Penelokan & Kedisan & III & Gray Regosol & Settlement, garden mix & Heavy rain \\
\hline
\end{tabular}

Source: The results of the analysis to the field

Geological factors that influence the movement of the soil are the geological structure, the nature of the rock, the loss of the soil adhesive due to the natural process (dissolving), and the earthquake. The geological structure that influences ground motion is the contact of bedrock with rock weathering, cracks, rock layers, and fractures. Fracture zone is a weak zone resulting in reduced rock strength, resulting in many cracks that facilitate pervasive water (Surono, 2003).

Types of soil in the study sites include regosol, where this type of soil has loose properties and is dominated by sand. Soil types determine the potential for erosion and landslides. The loose soil easily passes the water into the cross section of the 
soil and potentially landslides compared to the massive soil. It can also be seen from the soil erodibility value (K). The value of $\mathrm{K}$ indicates whether or not the soil is eroding, the greater the value of $\mathrm{K}$, the more susceptible to erosion (Sitorus, 2001).

Land use in landslide location in sub district of Kintamani is mixed and cultivated garden. Land use like this, people only see in terms of results obtained without regard to the slope of the land and land conservation rules. Land with a slope above $15 \%$ is planted with seasonal crops without any terraces. Such a situation will facilitate landslides because there is no conservation action, supported by high rainfall, the type of sandy soil (regosol) and its geological structure.

According to the Directorate of Volcanology and Geological Hazard Mitigation (2005), landslides are caused by: (1) Natural factors, consisting of: (a) Geological conditions: weathered rocks, slope layers, claystone insertions, Earth, stragrafi and volcanoes; (b) Climate, especially high rainfall in slope areas; (c) Topographic conditions, especially steep slopes; (d) Water conditions, especially clogged drainage conditions, accumulation of water masses, deep erosion, dissolution and hydrostatic pressures; (e) Land cover reducing shear stress, eg critical soil; (f) Vibrations caused by earthquakes, explosions, engine vibrations, or vibrations of nearby vehicular traffic; (2) Human factors, consisting of: (a) Climb cutting on stone mining on steep slopes; (b) Landfill in the slope area; (c) Failure of a retaining wall structure; (d) Deforestation; (e) Agricultural systems with little regard for irrigation security; (f) Development of areas not offset by public awareness, so that General Spatial Plan is not adhered to which ultimately self-defeats; (g) Inadequate slope drainage system, and (h) Land use that does not pay attention to soil and water conservation principles. This is in agreement with Sutikno (1997) that the factors that affect the occurrence of land movement include: slope level

Referring to the geological map source, the sub district of Kintamani is a very steep area, with a thick layer of soil that is affected by alteration, weathering from the earth. Added to the geological structure of the surrounding area is very complex, and found many fault lines. However, the trigger of landslide is caused by the use of less secure land, meaning that it does not follow the rules of land conservation. To avoid a similar incident occurring in the area of landslide potential is to observe the emergence of cracks of soil. The characteristics of the landslide begin with the appearance of cracks in the slope parallel to the cliff, which usually occurs after rain. The sudden emergence of new springs, brittle cliffs and pebbles began to fall. Water is inundated if the rainy season, before the disaster landslide occurs the water immediately disappeared and the collapse of the land in large numbers.

\subsection{Mapping of Landslip Prone Areas}

The landslides occurring in several locations in sub district of Kintamani, Bangli Regency, Bali Province are due to high rainfall, steep slopes above $15 \%$ average, geological structure and regosol soil type (sand texture to sandy clay) and mixture garden land use and moorings without any soil and water conservation treatment. Efforts to prevent landslides are not to open rice fields and don't create a pond on the upper slopes near the settlement. Make terraces (swales) on steep slopes when building settlements. If there is a crack in the soil, immediately close the cracks of the soil and compact it so that the water does not enter the soil and through the crack. Do not cut the cliff of the road upright. Do not build erosion-prone riverside houses, cut down trees on the slopes, and build houses under cliffs. It should also be noted that the area or villages in sub district of Kintamani is upstream of one of the major rivers in Bali, namely the Ayung River, so the use of land should pay attention to the environmental conditions (BPDAS, 2009; Sumarniasih and Antara, 2017). This is supported by the opinion of Brook et al., (1991). Which states that landslides will occur when three conditions are met: (1) the slope is quite steep, (2) there is a rocky ground (rock) below the waterproof surface, and (3) there is enough water (rain) that enters the pores soil over an impermeable rock layer, so that the soil pressure to the slope increases. While Karnawati (2001) and Alhasanah (2006) stated that slopes are a very important factor in the process of landslide, but not always slopes or sloping lands with potential landslides, depending on rock conditions and slope soil, geological structure, rainfall, vegetation Cover, and land use on the slopes.

The mapping is based on field observation at each landslide point using Global Position System (GPS) equipment, so that in obtaining $\mathrm{x}$ and $\mathrm{y}$ axis at each landslide point, and combined with interview result with community around disaster area resulted Q-GIS-based digital map with attribute The results of field observations as presented in Figure 2. This digital map when clicked on a point yellow with Q-GIS and Google Earth will see the location of landslide-prone areas in some villages in sub district of Kintamani, Bangli Regency, Bali Province, Indonesia. 


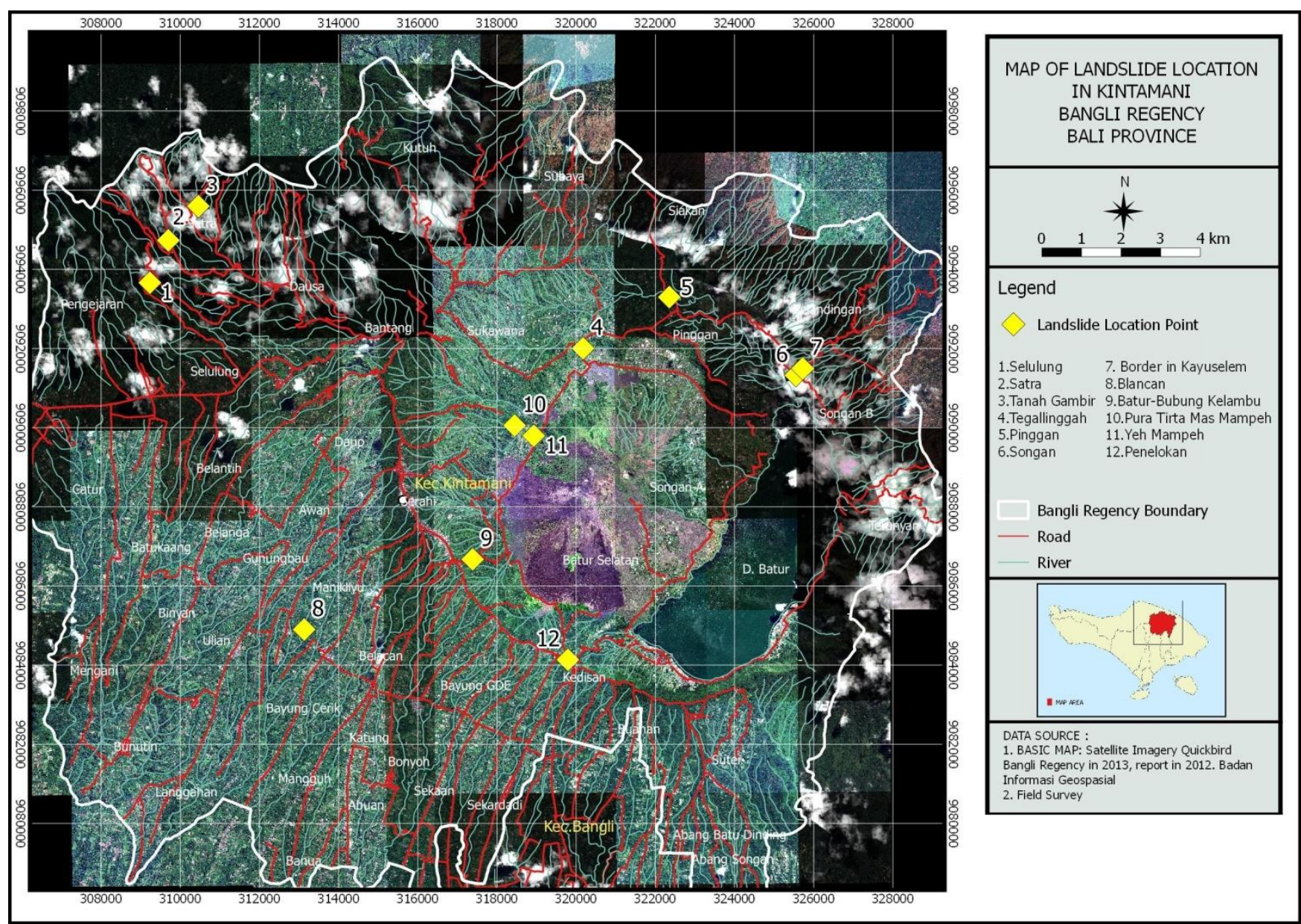

FigURE 2. LANDSLIDE MAP LOCATIONS IN SUB DISTRICT OF KINTAMANI, BANGLI REGENCY, BALI PROVINCE, INDONESIA

\subsection{Strategy to Overcome Landslide Risk}

The strategy to overcome landslides is to prohibit development in areas prone to landslide disaster, cover the land with agroforestry systems, create drainage ditches or ditches, and rules should be enforced and those who violate severe sanctions. This is in line with the opinion of Sumarniasih and Antara (2017), which says the use of local wisdom-based land can reduce erosion by up to $90 \%$, resulting in falling water that will cause erosion, causing landslides to be prevented by local wisdombased conservation methods.

According to Dardak (2006), the risk reduction of landslide disaster can be done by considering the density of the population, the area of awakening and the existence of productive land. The strategies that can be done, namely: (1) Conducting the management of the region through the regulation of human activities to protect people from disasters caused by humans. The objective is to prevent damage to environmental functions and to preserve regional protected functions and to avoid activities in the potential areas of disasters; (2) Reducing the density and activities of trhe people who living in areas with high risk of landslide disaster; (3) Determine the path and place of evacuation in case of landslide disaster; (4) Conducting the structural mitigation by carrying out physical development, such as the construction of terraces and brojong construction that can prevent and reduce the danger of landslides; (5) Establish rules or regulations that can reduce the impact of landslides in the form of zoning zones and prohibit the use of land in areas with the potential for landslide disasters; (6) Implementing the agroforestry program is expected to maintain land productivity. This is in line with Dubot and Watsala (2009) which states that measures that can be taken to reduce the risk of landslide disaster are (1) Housing is built outside the landslide threat area; (2) Slope cover should be solid; (3) density vegetation and bronjong manufacture; (4) The establishment of drains or ditches to prevent erosion or surface water flows; (5) Preparation of walls to protect the slope / cliff. 


\section{CONCLUSIONS AND RECOMMENDATIONS}

\subsection{Conclusions}

1. Based on observation and field identification, landslide disaster in sub district of Kintamani occurred in some vullages i.e. Selulung, Satra, Tanah Gambir, Tegallinggah, Pinggan, Songan, Kayu Selem, Blancan, Batur Bubung Kelambu, Pura Tanah Mas, Mampeh, Yeh Mampeh and Penelokan with Extent 144,36 ha. The factors that cause landslide disaster are: rainfall, geological structure, soil type, slope inclination, land use that does not pay attention to the rules of land conservation.

2. Mapping is based on field observations using GPS equipment combined with interviews with communities around the disaster site resulting in a Q-GIS-based digital map as presented in Figure 2.

3. Strategy to overcome landslides is to prohibit development in areas prone to landslide disaster, cover the land with agroforestry systems, create drainage ditches or ditches, and rules should be enforced and those who violate severe sanctions.

\subsection{Recommendation}

Avoiding or reducing the landslide disaster in the research area, stakeholders such as communities around in Sub District of Kintamani and Regional Governments should implement the strategies which formulated in this study.

\section{REFERENCES}

[1] Alhasanah, F. 2006. Mapping and Analysis of Landslide Prone Areas As well as the related mitigation efforts Using Geographic Information System. Thesis. Graduate Program in Bogor Agricultural University.

[2] Anwar, H.Z., Suwiyanto, Subowo, E., Karnawati, D., Sudaryanto and Ruslan, M. 2001. Application Satellite Imagery In dareah Determination of Landslide Prone. LIPI Geotechnology Research Center, Bandung.

[3] Bali Post. 2017. Bali at Landa Disaster. Publisher: Balipost. Denpasar

[4] Bappeda Bali and PPLH UNUD. 2006. Identification of Potential Study of Natural Disasters In the province of Bali, Research Reports, Regional Development Planning Board of Bali Province and the Research Center for Environmental research Udayana University, Denpasar.

[5] Barus B., and U.S. Wiradisastra, 2000, Geographic Information System, Remote Sensing Laboratory and Cartography, Soil Department, Faculty of Agriculture IPB, Bogor

[6] Ministry of Energy and Mineral Resources. 2009. Vulnerability Zone Map Land Movement of Bali province. Center for Volcanology and Geological Hazard Mitigation.

[7] Dardak, A.H. 2006. Spatial Planning Policy in Landslide Prone Areas Management. Material Papers in Workshop on Spatial Planning as a Forum to Minimize Potential Landslide Disaster. Jakarta, March 7, 2006.

[8] Dubot, Alice and Jayamanna Watsala.2009. Safer Cities 26: Using Risk Assessments to Reduce Landslide Risk, Asian Disaster Preparedness Center/ADPC. Bangkok

[9] Karnawati, D. 2001. Natural Disasters of the Indonesian Land Movement of 2000 (Evaluation and Recommendation). Department of Geological Engineering. Faculty of Engineering, University of Gadjah Mada, Yogyakarta.

[10] Ramadona, Aditya.L and Hari Kusnanto. 2010. Quantum GIS Applications For Environmental Information Systems. Publisher BPFE, Yogyakarta.

[11] Sitorus, S. R. P. 2006. Land Development Berpenutupan Stay In Control of Risk Factors of Erosion and Landslide. The Directorate General of Spatial Planning Department of Public Works. Jakarta.

[12] Subekti, R., Widodo, R.H., Meine van Noordwijk, Suryadi, I. Verbist, B. 2009. Water Monitoring in Watersheds. World Agroforestry Center-Southeast Asia Regional Office, Bogor Indonesia. $104 \mathrm{p}$

[13] Sumarniasih, Made Sri dan Made Antara. 2017. Conservation planning on eroded land based of local wisdom in Kintamani subdistrict, Province of Bali. Journal IOP Conf Series. Earth and Environment.

[14] Suripin. 2002. Soil and Water Resources Conservation. Andi. Yogyakarta.

[15] Surono. 2003. Potential of Geological Disaster in Garut Regency. Proceeding of Landslide Mitigation Workshops in Garut Regency. Government Garut regency.

[16] Sutikno. 1997. Landslide Mitigation. Ingredients Natural Disaster Counseling Land Movement. Jakarta. 